\title{
ASSOCIATION OF MICROSATELLITE MARKERS WITH PRODUCTION TRAITS IN SANTA INÊS AND CROSSBRED SHEEP
}

\author{
Cesar Daniel Petroli', Samuel Rezende Paiva², Tiago do Prado Paim¹, Concepta \\ Margaret McManus ${ }^{1}$
}

\author{
1 UNB \\ 2 EMBRAPA Recursos Genéticos e Biotecnologia \\ Correspondência: Concepta Margaret McManus: concepta@unb.br
}

\begin{abstract}
The objective of this work was to associate alleles of 13 microsatelite loci located on sheep chromosome 20 (Major Histocompatibility Complex) with performance and carcass traits as well as resistance to gastrointestinal parasites in 138 pure Santa Inês sheep and their crosses with Bergamasca, Texel and lle de France. The following loci were selected: BM1818, OarCP73, OarHH56, DYA, OLADRB, CP101, OMHC1, DQA2, DQA1, TFAP2A, DQBA27, Bf94_1, and INRA132. Data were analysed in Cervus and SAS ${ }^{\circledR}$ to determine heterozygosity levels and associations of markers with weight and carcass traits as well as faecal egg count. The markers used demonstrated high genetic variability between the individuals. For carcass traitss, eight significant associations $(p<0.05)$ were observed, as well as a positive association between fecal egg count and two markers on the ovine MHC.
\end{abstract}

Key Words: carcass; gastrointestinal parasites; Ovis Aries; production

\section{ASSOCIAÇÃO DE MARCADORES MICROSSATÉLITES COM CARACTERÍSTICAS DE PRODUÇÃO EM OVINOS SANTA INÊS E SEUS CRUZAMENTOS}

RESUMO: O objetivo deste estudo foi de associar alelos de 13 loci de microssatélites no cromossomo 20 de ovinos (Major Histocompatibility Complex - MHC) com características de desempenho e carcaça bem como resistência à parasitos gastrointestinais em 138 ovinos Santa Inês e seus cruzamentos com Bergamasca, Texel e lle de France. Os seguintes loci foram selecionados: BM1818, OarCP73, OarHH56, DYA, OLADRB, CP101, OMHC1, DQA2, DQA1, TFAP2A, DQBA27, Bf94_1, e INRA132. Os dados foram analisados em Cervus e SAS ® para determinar níveis de heterozigosidade e associações de marcadores com peso, carcaça e ovos por grama de fezes (OPG). Os marcadores mostraram alta variabilidade genética entre indivíduos. Para características de carcaça oito associações significativas $(p<0.05)$ foram observadas, bem como associação positiva entre OPG e dois marcadores da MHC ovina.

Palavras-chave: carcaça; parasitos gastrointestinais; Ovis Aries; produção 


\section{INTRODUCTION}

Sheep farming is of great importance for humanity, through the production of wool, pelts, meat and milk. Their production is present in almost all regions of the world in systems ranging from subsistence to highly technified.

Ruminant (beef and lamb) industries have to compete with other protein sources, especially pigs and poultry which have shown much higher growth rates, in part due to concerns over health, but mainly because of convenience and competitive price (Nogueira Filho \& Alves, 2005). In Brazil, the products of sheep origin, such as wool, meat and leather, tend not to be competitive when compared with other countries, which invest in genetic improvement of production traits (Morais, 2000; McManus et al., 2011; Paim et al., 2011).

Recent statistics indicate a marked flock growth in the Midwest Region of Brazil (Hermuche et al., 2012, 2013), mainly due to the insertion of sheep in integrated production systems for beef cattle (Barreto Neto, 2003). The same author notes that the prospects for growth in the region show an optimistic scenario for the next twenty years, when the effective herd size is expected reach around 20 million head.

In the search for decreasing the age at slaughter and improved carcass quality early developing breeds have been used to obtain lambs with higher weights in a shorter time, using feedlots, so that meet the growing demands of the consumer market for quality, taking into account regional variations (McManus et al., 2010). Imported breeds, because they are considered highly productive, have replaced well-adapted genotypes in farming systems in the tropics (Amarante et al., 2004) with varying outcomes (McManus et al., 2011).
Parasitic disease has a prominent place in the sheep industry and is currently one of the biggest bottlenecks to its development (McManus et al., 2009). Vieria et al. (1997) recognize that economic losses are high, due to retarded growth, weight loss, reduced food consumption, decreased milk production, low fertility and, in cases of large infections, high mortality rates. The emergence of strains of nematodes resistant to antihelmintics has hampered the treatment of this in ruminants. The ability of sheep to acquire and express immunity against gastrointestinal nematodes is genetically controlled and varies substantially between different breeds and between individuals of the same breed (Stear \& Murray, 1994; McManus et al., 2009). The age and breed of animals have influenced the proportion of subjects resistant or susceptible to nematodes in a population of sheep, as shown by Amarante et al. (2004) comparing Santa Ines (hair breed) with Suffolk sheep. Santa Ines have been shown to be more resistant to worms than Suffolk, Ile de France and Poll Dorset in some studies (Moraes et al., 2000; Bueno, et al., 2002; Bricarello et al., 2003; Amarante et al., 2004) but not in others (McManus et al., 2009).

Studies conducted in different countries show a negative correlation between faecal egg count (FEC) and weight gain or weight of sheep of different breeds, where more resistant animals are more productive (Amarante, 2004) although Eady et al. (1998) have shown the opposite for the production of wool in Merino sheep, where a positive correlation between FEC and wool production was found.

The maintenance of naturalized breeds depends directly on their insertion in existing production systems. It is necessary to identify important traits of these breeds that may play an important role for specific market niches. 
With the development of molecular techniques, it was found that in all eukaryotic DNA there exists hypervariable regions (repeated sequences), many of them expressing polymorphisms. The major histocompatibility complex (MHC) is involved in immune induction and is highly polymorphic (Benavides et al., 2002). In sheep, the region of the MHC is located on chromosome 20 (De Gotari et al., 1998) and its polymorphic portion studied and is known as OLA (Ovine Leukocyte Antigen).

This study aimed to analyze the genetic variability of the $\mathrm{MHC}$ region of the Santa Ines and its crosses using molecular markers on chromosome 20 and link this to performance traits and resistance to gastrointestinal parasites.

\section{MATERIAL AND METHODS}

Phenotypic data was collected on the farm of the Universidade de Brasília (UnB). Molecular analyses were carried out in the Animal Genetics and Plant Genetics Laboratories of EMBRAPA Genetic Resources and Biotechnology in the Federal District, Brazil.

One hundred and eighty two animals were phenotyped for birth and weaning weights as well as fecal egg counts and 44 of these (males) were slaughtered and carcass traits measured. The animals were of the Santa Ines breed or its crosses, mainly with Bergamasca.

Liveweights included birth weight (BW) and weaning weight (WW). The animals were dewormed soon after weaning and number of parasite eggs per gram of feces (FEC) counted every three weeks up to slaughter. The genera identified included Strongyloides, Strongyloidea, the protozoaria Eimeria and Moniezia. FEC was carried out according to McEwan (1992) with modifications of the Gordon and Whitlock technique using a McMaster chamber. Feces were collected directly from the rectum of the animal. Approximately $2 \mathrm{~g}$ of feces were placed in a sieve and diluted in $58 \mathrm{~mL} \mathrm{NaCl}$. The suspension was homogenized with a pipette, and an aliquot of the sample was collected and placed in the chamber. About 1 to 2 minutes after preparation, eggs were counted in both chambers. FEC is obtained by summing the number of eggs in both chambers and multiplied by 100 (Ueno \& Gonçalves, 1998).

After 12 weeks of monitoring, blood samples were taken from each animal. The material was collected in vacutainers containing anticoagulant (EDTA) and kept refrigerated until separation of lymphocytes.

Carcass traits included: fasting weight (PJP), empty carcass weight (PCV), hot carcass weight (PCQ), cold carcass weight (PCF), Loss during cooling (PRP), hemi-carcass weight (PHC), hot carcass yield (RCQ), cold carcass yield (RCF), carcass production (PVR), Weight of thoracic organs (POT), weight of abdominal organs (POA), skin weight (SKIN), leg, loin, shoulder, ribs, neck, and ribeye area (REA).

The genomic DNA extraction followed the protocol of Miller et al. (1988), with a few modifications. After extraction, the DNA was subjected to electrophoresis on $1 \%$ agarose gels stained with ethidium bromide to quantify and verify the quality of the material obtained. The amount of DNA obtained was quantified and analysed in a spectrophotometer.

After quantifying, the material was separated into two aliquots. The first aliquot was stored at $-80^{\circ} \mathrm{C}$ in the DNA and Tissue Bank of the Animal Genetics Laboratory at Embrapa Genetic Resources and Biotechnology, BrasiliaDF. The second aliquot was stored at $20^{\circ} \mathrm{C}$ at a concentration of $3 \mathrm{NG} / \mu \mathrm{l}$ for use in amplification via Polymerase Chain Reaction (PCR). 
To assess the genetic variability within the MHC sheep, microsatellite loci located within or adjacent to the MHC regions in sheep on chromosome 20 were used. The following loci were selected: BM1818, OarCP73, OarHH56, DYA, OLADRB, CP101, OMHC1, DQA2, DQA1, TFAP2A, DQBA27, Bf94_1, and INRA132.

Amplification of microsatellites was carried out using the PCR

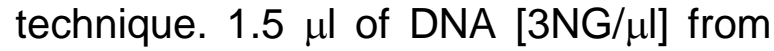
each sample was used and $1.0 \mu \mathrm{l}$ of $10 \%$ Tris-HCL (pH 8.4), $0.2 \mu \mathrm{l}-0.5 \mu \mathrm{l}$ of $\mathrm{MgCl}_{2}[1.0 \mu \mathrm{M}-2.5 \mu \mathrm{M}$ ], $0.8 \mu \mathrm{l}$ of dNTP [2.5 $\mu \mathrm{M}$ ], $1.0 \mu \mathrm{l}$ of BSA [1.0 mg / ml], 0.1 $\mu$ l Taq DNA polymerase (PHT) [5 Ud / $\mu l], 0.3 \mu \mathrm{l}$ of Primer $(\mathrm{F}+\mathrm{R})[10 \mu \mathrm{M}]$ added as well as water to make up the $10 \mu$ final volume.

PCR reactions were performed in thermal cyclers with a program that consisted of an initial denaturation step at $94^{\circ} \mathrm{C}$ for 5 minutes, 35 cycles with a denaturation at $94^{\circ} \mathrm{C}$ for 1 minute, annealing at temperatures ranging from $49^{\circ} \mathrm{C}$ to $65^{\circ} \mathrm{C}$ for 45 seconds (depending on the primer used), and $72^{\circ} \mathrm{C}$ for 1 minute for extension. At the end of 35 cycles a final extension at $72^{\circ} \mathrm{C}$ for 30 minutes was carried out.

The success of PCR amplification was observed in 2\% agarose gels stained with ethidium bromide. Along with the samples, $1 \mathrm{kB}$ standards (Invitrogen) were applied to gels for size comparison in the amplification of the fragments obtained. After viewing in agarose, samples were subjected to capillary electrophoresis in an automated sequencer, model $A B I$ Prism 3100 or 3700 (Applied Biosystems). Genotyping of the alleles was performed using Genotype and GenScan software, both from Applied Biosystems.

Genotypes were encoded to transform the multi-allelic to biallelic loci as follows: when a site had any one allele with a frequency of $40 \%$ or more, this was considered the main allele $(A)$ and the other lower frequency alleles were joined (B). Where no allele had a frequency equal to or greater than $40 \%$, the two most frequent alleles at each locus were coded together as allele $A$ and the rest were joined as $B$.

Observed and expected heterozygosities for all microsatellite loci used were estimated. The existence of association between molecular markers and phenotypic data for FEC and performance were analyzed using mixed model procedures (MIXED) and tests of mean comparisons for unequal sample sizes (Tukey-Kramer test at 5\%) using the statistical package SAS ${ }^{\circledR}$ (Statistical Analysis System, v.9.3, Cary, North Carolina). The fixed effects used included the marker and weaning age of the animals was included as a covariate. The FEC data were transformed by logarithms to stabilize variances.

\section{RESULTS AND DISCUSSION}

Of the 13 loci used, loci DQA2 and TFAP2A were discarded, as they did not amplify satisfactorily, resulting in 11 loci genotyped and analyzed. A total of 107 alleles were identified, all of which are polymorphic. The number of alleles ranged from 4 (INRA132 and DQA1) to 16 (DYA, BM1818, OLADRB). The average number of alleles per locus was 7.45. These are comparable to the 7.79 alleles for Red Engadin sheep found by Glowatzki-Mullis et al. (2007) analyzing 10 diverse breeds with a 19microsatellite multiplex. Baumung et al. (2006), on the other hand, found a mean of 15 alleles per locus using 25 microsatellite markers in 717 animals of 11 Austrian breeds. Average numbers of alleles vary with the markers and genotyping system used.

Santucci et al. (2007) found two groups of loci - the first highly polymorphic, with a mean of 16:11 
alleles (OLADRB and OMHC1) and a second lowly polymorphic group, with an average number of alleles per loci of 6.5 to 8.25. Alleles with an absolute frequency of less than 3 in the population were excluded from the analysis, since their influence and low frequency limits of the confidence estimates on the traits analyzed.

The number of alleles found by Bot et al. (2004) for the BF site was higher when compared with this work. Gruszczynska et al. (2002) identified 13:09 alleles for the OMHC1 in Polish and Polish Lowland Heath sheep. In this study we found 14 alleles belonging to the locus $\mathrm{OMHC}^{1}$ in purebred and crossbred animals, confirming the high polymorphism of this marker. Other authors have used loci in common with this work. For example, Janßen et al. (2002) analyzed the loci OarCP73, DYA and OarHH56 with 4, 6 and 5 alleles respectively. As for this work 6,12 and 8 alleles respectively were identified for these markers. According to Andersson et al. (1996), these polymorphisms are the result of long evolutionary processes from gene mutations. Part of our results here may be because our samples included mainly hair sheep, which have undergone a different evolutionary process from wool sheep used in these earlier studies.

For the group of 44 animals with carcass traits (Table 1), the expected heterozygosity $(\mathrm{He})$ was higher than the observed $(\mathrm{Ho})$ in all of the loci, except Bf94_1, which had same value for both (0.51). BM1818 had the highest value of 0.86 and the lowest was DQBA27 of 0.15 (Table 1). There were seven loci with heterozygosity coefficients above $50 \%$. OarCP73, DQA1 and INRA132 had low values of $15 \%, 31 \%$ and $35 \%$ respectively. These observations may be due to the occurrence of null alleles at some loci, or nonrandom mating, coupled with a reduction of heterozygosity due to genetic drift.
Heterozygosity or genetic diversity is less sensitive to variations in sample size compared to other measures, such as the percentage of polymorphic loci and mean number of alleles per locus and also is easy to interpret in genetic terms (Brown \& Weir, 1983).

Several studies have shown that the coefficient of expected heterozygosity for locus OLADRB1 is high, around $98 \%$ for Merino and $96 \%$ in Polish Heath Sheep (Gruszczynska, 1999; Gruszczynska, et al., 2000). This study also used OLADRB, with values of expected heterozygosity of $81 \%$, giving high variability, although not as high as in the studies cited above. Polish Lowland and Polish Heath Sheep showed a heterozygosity of $79 \%$ and $82 \%$, respectively, for OMHC1, which shows a high variability for these two breeds of sheep (Gruszczynska et al., 2002). Here, for the same marker, we obtained a similar level of heterozygosity (77\%).

Table 1 - Genetic diversity of 11 loci located on chromosome 20 for animals with carcass data

\begin{tabular}{ccccccc}
\hline & \multicolumn{3}{c}{ Carcass Traits } & \multicolumn{3}{c}{ Weight and Faecal Egg Count } \\
Locos & $\mathrm{N}^{*}$ Alleles & $\mathrm{Ho}$ & $\mathrm{He}$ & $\mathrm{N}^{\circ}$ Alleles & $\mathrm{Ho}$ & $\mathrm{He}$ \\
\hline OMHC1 & 6 & 0.59 & 0.76 & 6 & 0.64 & 0.77 \\
DQA1 & 3 & 0.03 & 0.26 & 4 & 0.06 & 0.31 \\
Bf94_1 & 5 & 0.37 & 0.47 & 5 & 0.51 & 0.51 \\
OLADRB & 9 & 0.67 & 0.86 & 16 & 0.77 & 0.81 \\
BM1818 & 10 & 0.30 & 0.87 & 16 & 0.36 & 0.86 \\
DYA & 12 & 0.55 & 0.86 & 16 & 0.50 & 0.84 \\
OarHH56 & 6 & 0.50 & 0.73 & 6 & 0.55 & 0.73 \\
DQBA27 & 3 & 0.08 & 0.66 & 5 & 0.04 & 0.46 \\
CP101 & 6 & 0.15 & 0.63 & 6 & 0.18 & 0.67 \\
INRA132 & 3 & 0.35 & 0.44 & 4 & 0.17 & 0.37 \\
OarCP73 & 3 & 0.15 & 0.55 & 5 & 0.11 & 0.15 \\
\hline Ho-observed heter ozygosis; He - expected heterozygosis & & &
\end{tabular}

In analyzing the association of 18 performance and carcass traits evaluated for this group, seven had a significant association $(\mathrm{p}<0.05)$ with some site (Table 2). High significance was found for half carcass and shoulder weights, both associated with BM1818 $(p<0.0001)$. Locus BM1818 showed that $\mathrm{AB}$ and $\mathrm{BB}$ genotypes (Table 2) were associated with higher average weights $(1.25 \pm 0.55$ and $1.07 \pm 0.16 \mathrm{~kg}$, respectively) than AA. Several traits also were significantly associated with other markers, such as the ham and skin weights with DQBA27 and OLADRB 
respectively $(p=0.002)$. Leg, skin and abdominal organ weights were associated with loci BM1818, OarCP73 and DYA, respectively $(p=0.004)$.

Highest averages for PHC were obtained in animals of genotype BB of BM1818 (5.28 \pm 0.77) and DQBA27 $(5.80 \pm 0.88)$ markers. The same was found for BM1818 and leg weight (BB = $1.88 \pm 0.30$ ), indicating that genotypes $A A$ or $A B$ should not be selected as this is the carcass cut with the highest monetary value.

The association found between weight of the loin and the locus DYA showed higher averages for genotype BB $(0.31 \pm 0.05)$ than the other genotypes (AA and $B B$ ) which showed no significant differences between their averages.

The weight of abdominal organs was associated with CP101 and DYA loci, but showed no statistical differences between means of genotypes. For skin weight at the OarHH56 locus, the genotypes associated with heavier weights in the phenotype were AA (4.78 $\pm 1.41)$ and BB (3.80 \pm 0.91$)$. Animals ruled out in the selection process should not have the allele with higher frequency (BB).

The low number of genotyped animals may influence the association test, and validation of data in commercial populations is necessary before the results are applied in breeding programs. Several carcass traits were associated with the MHC loci used in this work. The MHC is associated with a wide range of production traits in livestock, although sheep have been poorly characterized (Bot et al., 2004). Studies such as those conducted by Paterson et al. (1998), used some of the loci that were employed in this work (OLADRB, OarHH56 and BM1818) and found an association between specific MHC alleles and body weight in Soay sheep, confirming the data presented in this study.

The absence of genotypes for some of the loci should be noted (Table 2). The locus DQBA27 for leg weight showed no heterozygote genotype (AB) as did half carcass weight at the same locus. In the case of locus OarCP73 for Skin weight genotype, BB was absent.

In the second group of animals analyzed, heterozygosity results were similar to the first group (Table 1). The larger $\mathrm{Ho}$ than $\mathrm{He}$ continued in all cases. The locus BM1818 remained as the highest value with $\mathrm{He}(0.87)$. The locus of lowest $\mathrm{He}$ was seen in DQA1 with a value of 0.26 . Eight loci with a coefficient of more than $50 \%$ heterozygosity were seen in this group of animals.

For most loci (OLADRB, BM1818, DYA, DQBA27, INRA132 and OarCP73) He values increased from the first to the second group. On the other hand, for some loci He was lower in the group with the largest number of animals $(\mathrm{OMHC} 1$, DQA1, Bf94_1 and CP101). OarHH56 showed no difference in He between the two groups of animals (0.77).

\begin{tabular}{|c|c|c|c|c|c|c|c|c|}
\hline \multirow[b]{2}{*}{ Trait $^{1}$} & \multirow[b]{2}{*}{ Locus } & \multirow{2}{*}{$\mathrm{Sig}^{2}$} & \multicolumn{6}{|c|}{ Genotype } \\
\hline & & & Mean $^{3}$ & SD & Mean $^{3}$ & SD & Mean $^{3}$ & SD \\
\hline \multirow[t]{2}{*}{ Leg } & $B M 1818$ & 0.004 & $1.78^{\mathrm{ab}}$ & 0.23 & $1.88^{\mathrm{a}}$ & 0.3 & $1.59^{\circ}$ & 0.41 \\
\hline & DQBA27 & 0.002 & $1.65^{\circ}$ & 0.14 & $2.05^{a}$ & 0.3 & - & - \\
\hline Back & DYA & 0.03 & $0.26^{\circ}$ & 0.06 & $0.31^{\mathrm{a}}$ & 0.05 & $0.26^{\circ}$ & 0.05 \\
\hline \multirow[t]{2}{*}{$\mathrm{HC}$} & $B M 1818$ & $<0.0001$ & $5.01^{30}$ & 0.69 & $5.28^{\mathrm{a}}$ & 0.77 & $4.70^{\circ}$ & 0.98 \\
\hline & DQBA27 & 0.01 & $4.64^{\circ}$ & 0.47 & $5.80^{\mathrm{a}}$ & 0.88 & - & - \\
\hline Shoulder & $B M 1818$ & $<0.0001$ & $1.01^{\circ}$ & 0.11 & $1.07^{\circ}$ & 0.16 & 1. $25^{\mathrm{a}}$ & 0.55 \\
\hline \multirow[t]{3}{*}{ Skin } & OarHH56 & 0.03 & $4.78^{\mathrm{a}}$ & 1.41 & $3.80^{\mathrm{ab}}$ & 0.91 & $3.32^{\circ}$ & 0.74 \\
\hline & OarCP73 & 0.004 & $3.75^{\mathrm{a}}$ & 1.03 & - & - & $4.80^{2}$ & 1.58 \\
\hline & OLADRB & 0.02 & $3.37^{\mathrm{a}}$ & 0.97 & $4.00^{\mathrm{a}}$ & 1.5 & $3.81^{\mathrm{a}}$ & 1.08 \\
\hline \multirow[t]{2}{*}{$\mathrm{AO}$} & CP101 & 0.05 & $0.52^{\mathrm{a}}$ & 0.03 & $0.55^{\mathrm{a}}$ & 0.06 & $0.49^{2}$ & 0.06 \\
\hline & DYA & 0.04 & $0.54^{\mathrm{a}}$ & 0.07 & $0.55^{\mathrm{a}}$ & 0.05 & $0.50^{\mathrm{a}}$ & 0.04 \\
\hline TO & OLADRB & 0.002 & $0.78^{\circ}$ & 0.09 & $0.96^{\circ}$ & 0.25 & $0.82^{\circ}$ & 0.05 \\
\hline
\end{tabular}

Between birth weight (BW) and weaning weight (WW) and the loci genotyped, only the WW was statistically associated $(p<0.05)$ with three loci (DQBA27, OarCP73 and Bf94_1). The significance values obtained were 0.003 , 0.0006 and 0.026 , respectively (Table $3)$. 
Petroli et al. (2014)

Table 3 - Number of observations (N), Average and Standard Deviation (SD) traits by genotype in a population of sheep.

\begin{tabular}{|c|c|c|c|c|c|c|c|c|}
\hline \multirow{3}{*}{ Trait $^{1}$} & \multirow[b]{3}{*}{ Locus } & \multirow{3}{*}{ Sig. $^{2}$} & \multicolumn{6}{|c|}{ Genotype } \\
\hline & & & \multicolumn{2}{|l|}{ AA } & \multicolumn{2}{|c|}{ BB } & \multicolumn{2}{|c|}{$A B$} \\
\hline & & & Mean $^{3}$ & $\mathrm{SD}$ & Mean $^{3}$ & SD & Mean $^{3}$ & $\mathrm{SD}$ \\
\hline \multirow[t]{3}{*}{ WW } & DQBA27 & 0.003 & $17.42^{\mathrm{a}}$ & 2.38 & $13.52^{\circ}$ & 4.24 & $17.67^{\mathrm{a}}$ & 2.49 \\
\hline & OarCP73 & 0.0006 & $13.74^{30}$ & 4.11 & $16.96^{\mathrm{a}}$ & 2.22 & $9.25^{\circ}$ & 1.06 \\
\hline & Bf94_1 & 0.026 & $15.72^{\mathrm{a}}$ & 3.66 & $15.47^{\mathrm{a}}$ & 4.51 & $12.49^{\circ}$ & 3.99 \\
\hline FEC1 & INRA132 & 0.047 & $4.14^{\circ}$ & 0.42 & $4.54^{a}$ & 0.76 & $4.08^{\circ}$ & 0.40 \\
\hline \multirow[t]{2}{*}{ FEC2 } & OarHH56 & 0.055 & $1.79^{\mathrm{a}}$ & 1.28 & $1.09^{\circ}$ & 0.74 & $1.15^{a b}$ & 0.84 \\
\hline & CP101 & 0.023 & $0.27^{\circ}$ & 0.60 & $0.50^{\mathrm{ab}}$ & 0.55 & $0.92^{3}$ & 0.55 \\
\hline
\end{tabular}

Using Tukey's test, the highest average was found using DQBA27 and for PD was the AA genotype (17.42 \pm 2.38) and $A B(17.67 \pm 2.49)$. Thus, selection for the individuals with the most frequent allele in the population should lead to improvement in these traits. In the case of OarCP73 locus, the WW phenotype was associated with BB was (16.96 \pm 2.22), favoring the selection of individuals with the lowest frequency of alleles if looking for an increase in weight at weaning. As for the loco Bf94_1, mean PD was higher in the AA genotype $(15.72 \pm 3.66)$ but did not differ statistically from the BB genotype $(15.47 \pm 4.51)$, which is why, in this case, the heterozygous individuals should be left out of the selection process.

FEC was also significantly associated ( $p<0.05)$ with three loci, INRA 132, CP101 and OarHH56; the first site for the nematode Strongyloides and the second and third loci are related to the protozoan Eimeira (Table 3).

The AA genotype of CP101 has the lowest average phenotypic value for FEC. This could be associated with a possible resistance to this parasite. In a process of selection of individuals resistant to this parasite, individuals would be selected who have the genotype with higher frequency alleles in this population. For the INRA132 site, the homozygous $A A$ and heterozygous $A B$ did not show statistically different averages (4.14 \pm 0.42 and $4.08 \pm 0.40$, respectively), although the levels were lower than for the BB genotype. In contrast, OarHH56 had the lowest FEC for the genotype BB (1.09) and highest for the the AA genotype (1.79).

Bot et al. (2004) demonstrated the existence of an association between alleles of locus $\mathrm{Bf}$ and high weights of wool Merino ewes. In this work, the site Bf94_1, was associated with weight at weaning for the most frequent allele at this

marker.

The identification of genetic markers associated with resistance/susceptibility to nematodes allows selection of a genotype soon after birth without having to wait for the expression of the phenotype (Benavides et al., 2002). Selection for resistance to gastrointestinal parasites is a difficult character to measure; the assessment could speed up the rate of selection (Beh et al., 2002).

Several studies have been published linking nematode resistance to QTLs found on chromosomes 1 (DiezTanson et al., 2002; Beh et al., 2002), 2 (Davies et al., 2006), 3 (Coltman et al., 2001; Beh et al., 2002; Paterson et al., 2001, Davies et al., 2006), 6 (Beh et al., 2002; Schwaiger et al., 1995), 14 (Davies et al., 2006) and 20 (Schwaiger et al., 1995; Janßen et al., 2002, Davies et al., 2006). The QTL on chromosome 20 found by these authors include DRB1, OARCP73, DYMS1 and BM1815. The only marker used in this study in this list (OARCP73) was found to have an association with weaning weight but not FEC. Nevertheless the indicator traits used by Janßen et al. (2002) was heamotocrit level and not fecal egg count as in the present study. Davies et al. (2006) found two QTL on chromosome 20 close to the MHC regions. In this case they did not specify specific microsatellites but these QTL were close to DRB1, OLARB, PMHC1 and CP73.

According to Janßen et al. (2002), the DYA gene which is near the DYMS1 site may be a possible candidate gene for resistance to Haemonchus contortus 
in sheep, although there are other studies that determined the absence of an effect of $\mathrm{MHC}$ genes in resistance of sheep against Haemonchus contortus (Blattman et al., 1993) or Trichostrongylus columbriformis (Hulme et al., 1993).

In sheep, the MHC region is located on chromosome 20 (De Gotari et al., 1998). This chromosome not only associated with resistance to nematodes but various other diseases, and contains candidate genes that influence immune function (Davies et al., 2006). According to these authors, the closely linked genes in the $\mathrm{MHC}$ are involved in antigen reaction in the vertebrate immune system. These MHC molecules have a primary immunological function of binding antigenic peptides on the surface of cells so that the antigenspecific T-cell receptors of lymphocytes can recognise them, thereby affecting the overall health of the animal and so influencing growth rate and carcass quality as seen in the present study.

\section{CONCLUSION}

Seven microsatellite markers on chromosome 20 showed significant associations with production traits in sheep. The presence of certain alleles could influence the action of immune response in individuals in this population. There is a considerable genetic variability in the $\mathrm{MHC}$ of sheep which also suggests that the loci of this region have an important role in immune function. The markers evaluated in this study demonstrate the potential of genes located on chromosome 20 as an additional tool in programs for markerassisted selection in animal breeding. The results of this study are still preliminary and need further validation sampling and other commercial populations.

\section{ACKNOWLEDGEMENTS}

The authors wish to thank CAPES and CNPq for scholarships, FAPDF and INCT-Pecuária for financial support

\section{REFERENCES}

AMARANTE, A.F.T.; BRICARELLO, P.A.; ROCHA, R.A. et al. Resistance of Santa Inês, Suffolk and lle de France lambs to naturally acquired gastrointestinal nematode infections. Veterinary Parasitology, v.120, n.1-2, p.91106, 2004.

ANDERSSON, L. Major Histocompatibility Complex Evolution. In: The Major Histocompatibility Complex Region of Domestic Animal Species. Ed. Schook L.B.; Lamont S.J. CRC Press: p.1-15, 1996.

BARRETO NETO, A.D. A cadeia produtiva das carnes caprinas. In: SEMINÁRIO NORDESTINO DE OVINOCAPRINOCULTURA, 6., Recife, 2003, Anais... Recife, 2003, Sociedade Pernambucana de Medicina Veterinária, p.171177.

BAUMUNG R.; CUBRIC-CURIK V.; SCHWEND K. et al. Genetic characterization and breed assignment in Austrian sheep breeds using microsatellite marker information. Journal of Animal Breeding and Genetics, v.123, p.265271, 2006.

BEH, K.J.; CALLAGHAN, M.J.; HULME, D.J. A search for genes affecting gastrointestinal parasite resistance in sheep. In: XXVI INTERNATIONAL CONFERENCE ON ANIMAL GENETICS. 1998, Proceedings.., Auckland, 1998, p.102.

BEH, K. J.; HULME, D.J.; CALLAGHAN, M.J.; et al. A genome scan for quantitative trait loci affecting resistance to Trichostrongylus colubriformis in sheep. Animal Genetics, v.33, p.97-106, 2002

BENEVIDES, M.V.; SACCO, A.M.S.; WEIMER, T.A.; et al. Marcadores genéticos como indicadores de resistência a parasitos gastrintestinais em ovinos. Bagé: Embrapa Pecuária Sul, 2002. 20 p. (Embrapa Pecuária Sul. Documentos, 31).

BLATTMAN, A.N.; HULME, D.J.; KINGHORN, B.P.; et al. A search for associations between major histocompatibility complex restriction 
fragment length polymorphism bands and resistance to Haemonchus contortus infection in sheep. Animal Genetics, v.24, p.277-282, 1993.

BOT, J.; KAELSSON, L.J.E.; GREEF, J.; et al. Association of the MHC with production traits in Merino ewes. Livestock Production Science, v.86, n.1-3, p.85-91, 2004.

BRICARRELLO, P.A.; AMARANTE, A.F.T.; HOUDIJK, J.G.M. et al. Influence of dietary supply on resistance to infection with Haemonchus contortus in lle de France and Santa Inês lambs. In: THE BRITISH SOCIETY OF ANIMAL SCIENCE, York.

Proceedings...York: BSAS, p. 93, 2003.

BROWN, A.H.D.; WEIR, B.S. Measuring genetic variability in plant populations. In: Isozymes in plant genetics and breeding. Part A. Eds: Tanksley, S.D. \& Orton, T.J. Amsterdam: Elsevier Science Publishers, p.73-86, 1983.

BUENO, M.S.; CUNHA, E.A.; VERÍSSIMO, C.J. Infección por nematódos en razas de ovejas carnicas criadas intensivamente en la región del sudeste del Brasil. Archivos de Zootecnia, v.51, p. 273-280, 2002.

COLTMAN, D. W.; WILSON, J. G.;

PILKINGTON, et al. A microsatellite polymorphism in the gamma interferon gene is associated with resistance to gastrointestinal nematodes in a naturally parasitized population of Soay sheep. Parasitology v.122, p.571-582, 2001

DAVIES, G.; STEAR, M.J.; BENOTHMAN, M.; et al. Quantitative trait loci associated with parasitic infection in Scottish blackface sheep. Heredity v.96, p.252-258, 2006

DE GOTARI, M.J.; FREKING, B.A.; CUTHBERTSON, R.P.; et al. A secondgeneration linkage map of the sheep genome. Mammalian Genome, v.9, p.204-209, 1998.

DIEZ-TASCÓN, C.; MCDONALD, P. A.; DOODS, K. G.; et al. A screen of chromosome 1 for QTL affecting nematode resistance in an ovine outcross population. In: $7^{\mathrm{TH}}$ WORLD CONGRESS ON GENETICS APPLIED TO LIVESTOCK PRODUCTION, 2002,

Proceedings..., Montpellier, France, 2002.

EADY, S.J.; WOOLASTON, R.R.; LEWER, R.P. Resistance to nematode parasites in Merino sheep: correlation with production traits.

Australian Journal of Agricultural Research, v.49, p.1201-1211, 1998.
GLOWATZKI-MULLIS, M.L.; MUNTWYLER, J.; GAILLARD, C. Cost-effective parentage verification with 17-plex PCR for goats and 19plex PCR for sheep. Animal Genetics v.38, n.1, p.86-88, 2007.

GRUSZCZYNSKA, J. Polymorphism of the OLADRB1 (MHC Class II) gene in German Merino sheep. Annals of Warsaw Agricultural University - SGSW, Animal Science, v.35, p.125-132, 1999.

GRUSZCZYNSKA, J.; CHARON, K.M.; SWIDEREK, W. et al. Microsatellite polymorphism in locus OMHC1 (MHC Class I) in Polish Heath sheep and Polish Lowland sheep (Zelazna variety). Journal of Applied Genetics, v.43, n.2, p.217-222, 2002.

HERMUCHE, P.; SILVA, N. C.; GUIMARÃES, R.F.et al.. Dynamics of sheep production in Brazil using principal components and maps of auto-organization characteristics. RBC. Revista Brasileira de Cartografia v.64, n.6, p.821-832, 2012.

HERMUCHE, P.; MARANHAO, R.L.A.; GUIMARÃES, R.F. et al. Dynamics of Sheep Production in Brazil. ISPRS International Journal of Geo-Information, v.2, p.665-679, 2013.

HULME, D.J.; NICHOLAS, F.W.; WINDON, R.G. et al. The MHC class II region and resistance to an intestinal parasite in sheep. Journal of Animal Breeding and Genetics, v.110, p.459472, 1993

JANBEM, M.; WEIMANN, C.; GAULY, M.; et al. Association between infections with Haemonchus contortus and genetic markers on ovine chromosome 20. In: $7^{\text {TH }}$ WORLD CONGRESS ON GENETICS APPLIED TO LIVESTOCK PRODUCTION, 2002, Proceedings..., Montpellier, France, 2002.

MCEWAN, J.C.; MASON, P.; BAKER, R.L. et al. Effect of selection for productive traits on internal parasite resistance in sheep. Proceedings of the New Zealand Society for Animal Production, v.52, p.53-56, 1992.

MCMANUS, C.; LOUVANDINI, H.; GUGEL, R.; et al. Skin and coat traits in sheep in Brazil and their relation with heat tolerance. Tropical Animal Health and Production, v.43, n.1, p.121-126, 2011

MCMANUS, C.; LOUVANDINI, H.; PAIVA, S.R.; et al. Genetic factors of sheep affecting 
gastrointestinal parasite infections in the Distrito Federal, Brazil. Veterinary Parasitology, v.166, n.3-4, p.308-313, 2009.

MCMANUS, C.; PAIVA, S.R.; ARAÚJO, R.O. Genetics and breeding of sheep in Brazil. Revista Brasileira de Zootecnia, v.39, Suppl. p.236-246, 2010.

MCMANUS, C.; PINTO, B.F.; MARTINS, R.F.S.; LOUVANDINI, H. ; PAIVA, S.R. ; BRACCINI

NETO, J.; PAIM, T.P. Selection objectives and criteria for sheep in Central Brazil. Revista

Brasileira de Zootecnia, v. 40, p. 2713-2720, 2011.

MORAES, F.R.; THOMAS-SOCCOL, V.; ROSSI JUNIOR, P. et al. Susceptibilidade de ovinos das raças Suffolk e Santa Inês à infecção natural por tricostrigilídeos. Archives of Veterinary

Science, v.6, n.1, p.63-69, 2000.

MORAIS, O.R. O melhoramento genético dos ovinos no Brasil: situação atual e perspectivas para o futuro. In: SIMPÓSIO NACIONAL DE MELHORAMENTO ANIMAL, Anais... Belo Horizonte: FEPMVZ, p.266-272, 2000.

NOGUEIRA FILHO, A.; ALVES, M.O.

Potencialidades da cadeia produtiva da ovinocaprinocultura na região nordeste do Brasil. Available in:

http://www.bnb.gov.br/content/aplicacao/cadeias _produtivas/ovinocaprinocultura/docs/ potencialidades\%20da\%20ovinocaprinocultura.d oc. Acesso em 17/03/2011

PAIM, T.P.; CARDOSO, M.T.M.; BORGES, B.O. et al. Estudo econômico da produção de cordeiros cruzados confinados abatidos em diferentes pesos. Ciência Animal Brasileira, v.12, n.1, p. 48-57, 2011.

PATTERSON, K.A.; McEWAN, J.C.; DODDS, K.G.; et al. Fine mapping a locus affecting host resistance to internal parasites in sheep. In: Association for Advancement in Animal Breeding and Genetics, 2001, Proceedings...v. 13, Queenstown, New Zealand, p. 91-94, 2001.

PATERSON, S.; WILSON, K.; PEMBERTON, J.M. Major Histocompatibility Complex variation associated with juvenile survival and parasite resistance in a large unmanaged ungulate population (Ovis aries L.) Proceedings of the National Academy of Science of the United States of America, v.98, p.3714-3719, 1998.
SANTUCCI, F.; IBRAHIM, K.M.; HEWIT, G.M. Selection on MHC-linked microsatellite loci I sheep populations. Heredity, v.99, p.340-348, 2007.

SCHWAIGER, F.W.; GOSTOMSKI, D.; STEAR, M.J.; et al. An ovine Major Histocompatibilty Complex DRB1 allele is associated with low faecal egg counts following natural, predominantly Ostertagia circumcincta infection. International Journal of Parasitology, v.25, p.815-822, 1995.

STEAR, M.J.; MURRAY, M. Genetic resistance to parasitic disease: particularly of resistance in ruminants to gastrointestinal nematodes.

Veterinary Parasitology, v.54, p. 161-176, 1994.

UENO, H.; GONÇALVES, P.C. Manual para diagnóstico das helmintoses de ruminantes. 4 ed. Salvador BA: Gráficos Especializados Limitada, 14p, 1998.

VIEIRA L.S.; CAVALCANTE A.C.R.; XIMENES L.J.F. Epidemiologia e controle das principais parasitoses de caprinos nas regiões semi-áridas do Nordeste. Embrapa Caprinos, Circular Técnica, Embrapa Caprinos, Sobral, CE. 49p, 1997. 